\title{
Corporate taxation in Denmark and the international challenge*
}

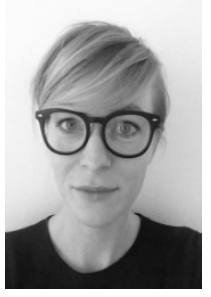

Economist, Head of Section Anna Holst Birket-Smith The Ministry of Taxation

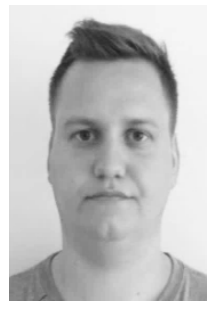

Economist, Special Adviser Anders Fuglsig Larsen The Minnistry of Taxation

Abstract: We study the development in the Danish corporate income tax base and the corporate income tax revenue in the period from 1990 until present. Measured in per cent of GDP the CIT base has out-paced the revenue due to parallel CIT rate cuts and base broadening reforms. We seek to explain the development in the CIT base and discuss whether this is threatened by base erosion and profit shifting.

Describing the development in the CIT tax base is a comprehensive and complex task and to pin-point one single cause is not possible. But it is possible to point to elements which have contributed to the development. We conclude that there exists a challenge in terms of international tax competition but find no evidence of the Danish CIT base suffering from this. The challenge for policy makers is designing a tax system which on one side secures sufficient revenue and on the other hand is internationally competitive.

Keywords: Corporate income tax, base broadening, profit shifting.

* We are grateful for useful comments and suggestions from Niels Kleis Frederiksen, Rasmus Igum and Lise Bo Nielsen. 


\section{Introduction}

Fighting base erosion and profit shifting due to increasing mobility of tax bases caused by increasing cross boarder corporate activity is proving to form a challenging task for tax policy makers. The task of policy makers is a two edged sword: on the one hand tax policy must be designed to secure a solid tax base and defend this from tax avoidance, and on the other hand policy makers must adapt to an increasing level of international tax competition, in order to attract investments. With these challenges in mind this paper focuses on the development in the Danish CIT-base.

\section{Tax avoidance}

Fighting tax avoidance is part of the international challenge and has for quite some time been subject to public debate and is still high on the political agenda in Denmark. The current government has put a lot of emphasis into stressing, that tax avoidance can not be tolerated neither from a legal nor from a moral viewpoint. The concern relating to multinational enterprises' (MNEs) profit shifting is twofold; firstly there is a concern, that profits are transferred to low or no-tax countries thus harming tax revenue, secondly there is a strong concern that when multinational enterprises avoid paying taxes in Denmark the overall willingness to pay taxes is negatively affected.

Hence, the twofold concern covers not only a financial issue relating to tax revenue but also an issue of what is perceived as fair. In the public debate on MNEs' tax avoidance the latter concern relating to fairness and MNE's moral obligation to co-finance the Danish welfare system is undoubtedly the most prevalent at present.

Since the early 2000s politicians have been increasingly preoccupied with MNEs having continued deficits therefore paying zero CIT. Several legislative steps have been taken in order to combat tax avoidance, e.g. CFC-rules, rules on hybrids, and other tax related measures (see the section on tax reforms below and the legal part of the Danish national report). Apart from legal tax measures politicians have also engaged in other actions to curb tax avoidance and address the fear of revenue loss.

As an example of a course of action, the Danish tax authorities publish the so-called "open tax lists". The open tax lists were introduced due to a wish for more transparency on companies' tax payments. Since 2012 everyone has been able to gain access to CIT payments from companies, associations, and foundations subject to CIT in Denmark. The open tax lists for example show that from 2011 to 2012 
the share of companies paying CIT in Denmark has risen. However still only app. every third company pay CIT in Denmark.

As another example of a course of action, the former government in 2010 carried out an action plan in order to strengthen the effort in relation to zero-tax-paying MNEs. ${ }^{1}$

The analysis in the action plan showed that a rather large proportion of MNEs do not pay CIT in a given year. Depending on the type of corporation in question between 40 and 60 per cent of Danish MNEs do not pay CIT in a given income year, ${ }^{2} \mathrm{cf}$. Figure 1.

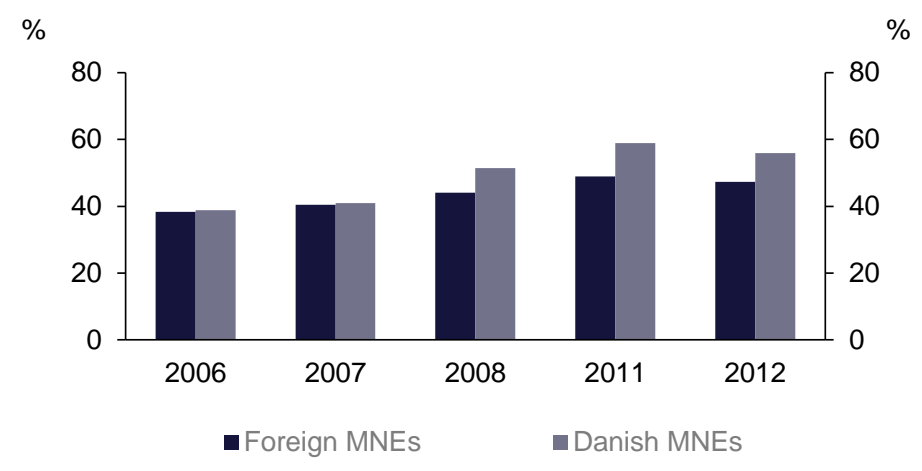

Figure 1. Share af zero-tax-payers

Source: The Danisk Ministry of Taxation

Figure 1 shows an increase in the shares of zero-tax-paying MNEs with the largest increase for Danish MNEs. With a share of 76 per cent Danish MNEs contribute with the vast majority of total CIT from MNEs, but even so in 2012 more than half (56\%) of the Danish MNEs did not pay any CIT.

1 Multinational enterprises where here defined as corporations with intragroup transaction of more than 10 million DKK in any given year in the period 2006-2010.The multinationals are categorized as foreign-owned or as Danish owned corporations, respectively. Within a given group there can be only one controlling company. If just one unit in a jointly taxed group has had intra-group transaction of more than 10 million DKK, the whole enterprise is regarded as multinational. If this controlling unit is foreign, the associated units are categorized as foreign-owned multinationals. On the other hand, if the controlling unit is Danish all units in the group are categorized as Danish-owned.

2 Corrected for the Danish mandatory joint taxation, the existence of associations and inactive corporations. 
This is a potential threat to the CIT base due to not only increasing international tax competition but also corporations' use of e.g. profit shifting in order to lower their tax payments.

\section{Taxation of capital - The development in CIT rate and revenue}

Since 1990 the CIT rate has been reduced from 40\% to 25\% in 2013 and will be reduced further to $22 \%$ in 2016 and onwards. Until 2007 the reduction of the CIT rate has been accompanied by an increase in the CIT base, cf. Figure 2 .

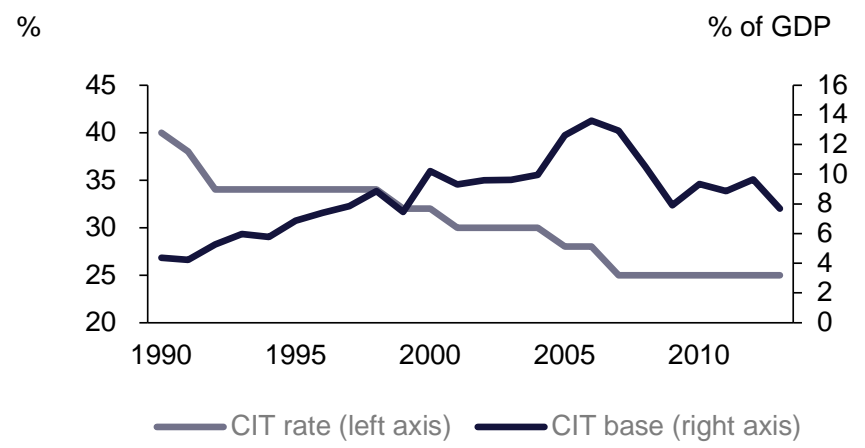

Figur 2. CIT rate and CIT base

Source: Statistics Denmark (Danish national accounts) and The Danish Ministry of Taxation. 


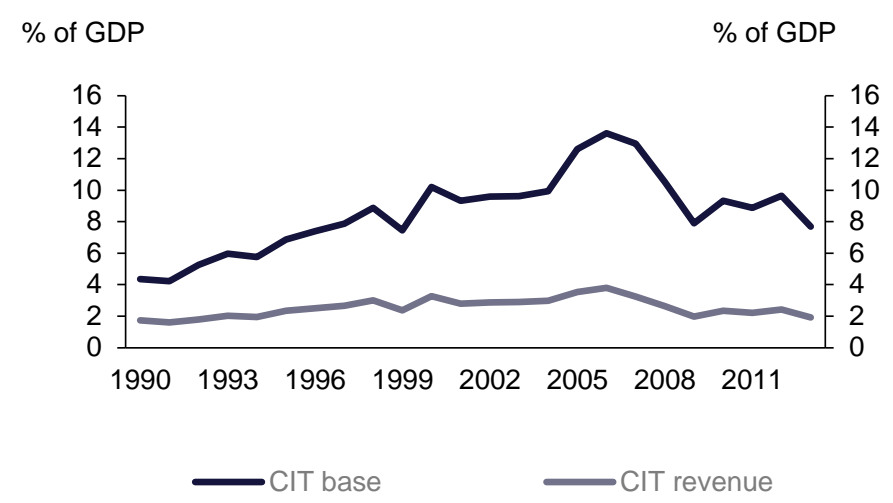

Figure 3. CIT base and revenue

Source: Statistics Denmark (Danish national accounts) and The Danish Ministry of Taxation.

From 1990 to 2005 the CIT rate was reduced from $40 \%$ to $28 \%$ and in that same period the tax base increased from around $4.5 \%$ pct. of GDP to around $12.5 \%$ of GDP. In the same period CIT revenue increased from $1.7 \%$ to $3.5 \%$, cf. figure 3 . The increase in the tax base thereby dominated the loss of revenue from reduced CIT rates.

The reductions of the CIT in this period were to a varying degree financed by initiatives increasing the tax base (cf. the section on tax reforms below), which explains part of the increase in the tax base. Other possible explanations to the development in the CIT base are changes in business cycles and structural changes in the Danish business sector i.e. an increase in the number of corporations and the privatization of large public companies in the 1990s. Finally the tax base may have increased due to the reduction of distortionary effects of the CIT concurrently with the lowered rate; increasing investments and less use of profit shifting which will be examined in the following.

In 2007 the CIT rate was reduced further to $25 \%$ as part of a larger restructuring of the taxation of corporations. The reduction was fully financed by increasing other taxes and by widening the tax base through reducing allowances and restricting the deductibility of net financing costs among other. The tax base does not appear to have increased following this restructuring of the taxation of corporation, but has instead dropped to the same level as in 2000, depicting the general macroeconomic environment.

The overall development in the CIT base until 2005 shows no indication that tax competition has led to base erosion and profit shifting. The drop in the tax base in 2007 coincides with the beginning of the recession, lower CIT rate and rules that reduces possibilities of income 
transformation and therefore also does not give evidence to increased base erosion and profit shifting.

The next section provides a brief run-through of CIT reforms since 1990 in order to describe the historical CIT rate cuts as well as the base broadening measures. Next this paper will look into some of the other determinants of the CIT base to give explanations of the development in the CIT base.

\section{Tax reforms}

To protect the CIT base and to align the Danish CIT rate to the international development several reforms of the Danish CIT have been carried out since 1990. Table 1 gives a brief overview of tax reforms involving the CIT from 1990 to 2007.

Table 1. CIT reforma from 1990 to 2007

\begin{tabular}{|c|c|c|}
\hline Year & $\begin{array}{l}\text { CIT rate } \\
\text { reduction }\end{array}$ & Financing/base widening \\
\hline 1990 & 40 to $38 \%$ & $\begin{array}{l}\text { Removal of corporations option to use the tax rules } \\
\text { for foundations and set aside } 25 \% \text { of profits and de- } \\
\text { duct it from taxable income. }\end{array}$ \\
\hline 1992 & 38 to $34 \%$ & $\begin{array}{l}\text { Restructuring of CIT payments to the income year } \\
\text { from the year after the income year. }\end{array}$ \\
\hline 1994 & - & $\begin{array}{l}\text { Removal of option to depreciate the value of inven- } \\
\text { tory and removal of } 50 \% \text { deductibility of foreign in- } \\
\text { come. }\end{array}$ \\
\hline 1999 & 34 to $32 \%$ & $\begin{array}{l}\text { Simplification of depreciation rates for building re- } \\
\text { sulting in all industrial and commercial buildings } \\
\text { being depreciated by the same rate. }\end{array}$ \\
\hline 2001 & 32 to $30 \%$ & $\begin{array}{l}\text { Lowering of depreciation rates on plant and ma- } \\
\text { chinery from } 30 \text { to } 25 \% \text {. }\end{array}$ \\
\hline 2004 & 30 to $28 \%$ & $\begin{array}{l}\text { Implement requirement that MNE's - if choosing in- } \\
\text { ternational joint taxation - must include income in } \\
\text { foreign based subsidiaries and branches if deficits is } \\
\text { to be included in taxable income. MNE's not choos- } \\
\text { ing international joint taxation would instead only } \\
\text { pay CIT of Danish activities. }\end{array}$ \\
\hline 2007 & 28 to $25 \%$ & $\begin{array}{l}\text { Adjustment of CFC-rules, limitation on deduction of } \\
\text { financing costs incl. EBIT-rule, reduction of depreci- } \\
\text { ation rates on buildings and plant and machinery } \\
\text { with extended longevity, increased taxation of share } \\
\text { income and adjustment of the taxation of the returns } \\
\text { on corporations portfolio investments. }\end{array}$ \\
\hline
\end{tabular}


Recent CIT rate reduction

In order to adapt to the international challenges as well as spurring investments, growth and employment, an extensive reform the Growth Plan DK (Vrkstplan DK) was agreed upon in the spring of 2013. Among a wide range of initiatives the CIT rate is gradually lowered from $25 \%$ in 2013 to $22 \%$ in 2016.

This reform is different from earlier reforms as the various tax cuts were not financed by widening the tax base or increasing other taxes. Instead the Growth Plan DK was primarily financed through reforms of student Grants and Loans Scheme, social securities and through lowering public spending. See box 1 below for the main elements of the Growth Plan DK. Box 1.

\section{Growth Plan DK - spring 2013}

In April 2013 the Danish government and parts of the opposition agreed upon a reform - Growth Plan DK - which is part of the government's goal of spurring economic growth rates. The Growth Plan DK is to:

- Improve GDP by 40 bn. DKK in 2020

- Free 12 bn. DKK in 2020 in the public sector for new initiatives

The reform includes many different initiatives. The main tax initiatives include:

- Gradual reduction of the CIT rate from $25 \%$ in 2013 to $22 \%$ in 2016

- Lower taxation of energy i.a. lower tax on electricity, lower tax on fuel used in industrial processes

- Road pricing for lorries not being introduced as originally planned

- Increased tax credits for R\&D-expenses

Other initiatives:

- Increased public investments

- Increased renovation of non-profit housing

The reform was primarily financed through reforms of the students' Grants and Loans Scheme, social securities and through lowering public spending.

The reform is estimated to increase GDP by 6 bn. DKK in 2020 with $3 \frac{1}{2}-4$ bn DKK stemming from the effects of lower CIT on investments and productivity. 
Expanding the CIT base has partially or fully contributed to financing the previous CIT rate reductions. However, the earlier years of continuing base broadening also implies that the possibility of ongoing broadening the base is limited. This does not mean that it is not possible to increase the tax base, but rather that it becomes increasingly difficult to find sound financing sources, and the political will to raise taxes is limited.

\section{Expansion of the CIT base}

As explained the reductions of the statutory CIT rate have been accompanied by an ongoing extension of the CIT base on a number of measurements during most of the period since 1990.

In the next part of the paper we investigate potential reasons for the development in the CIT base. First we briefly look at legislative measures. Next we look into the development in investments and capital taxation followed by a description of how attempts to reduce profit shifting can potentially widen the tax base. Finally, we search for alternative explanations for the CIT base development such as whether any specific sectors may contribute to the tax base development.

\section{Depreciation rates}

Various legislative steps have been taken in order to broaden the CIT base. These are described briefly in the tax reform section above and in the legal part the Danish national report. One base expanding measure which has been used frequently is the tightening of rules on depreciation rates.

In general depreciation rules is not a major concern in the public debate. However, the major Danish employer association, Danish Industries, has put forward a wish for the government to make an analysis of the depreciation rates in the tax laws compared to the true economic depreciation rates. The Ministry of Taxation has generally not shared this view, and depreciation rules have continually been tightened. One exception in the later years is the initiative the investment 
window, which for a limited period of time allowed companies to depreciate $115 \%$ of investments in new plant and machinery. ${ }^{3}$

As Figure 4 shows plant and machinery with an extended longevity, small ships, and infrastructure have been subject to a uniform depreciation rate until 2008 when three separate rates entered into force. Special rules apply for software which is subject to accelerated depreciation.

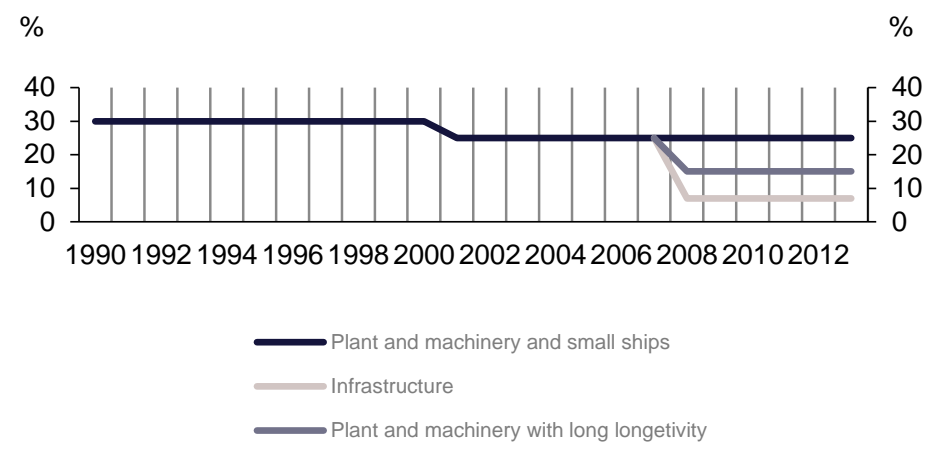

Figure 4. Plant and machinery

Source: The Danish Ministry of Taxation

3 The investment window was a temporary initiative as part of the tax reform of 2012. The basis for depreciation was increased by $115 \%$ for new investments in plant and machinery acquired in the period from May 30th 2012 to the end of 2013. The increased depreciation basis was depreciated by $25 \%$ annually corresponding to the rules in force applicable to the plant and machinery. 
$\%$

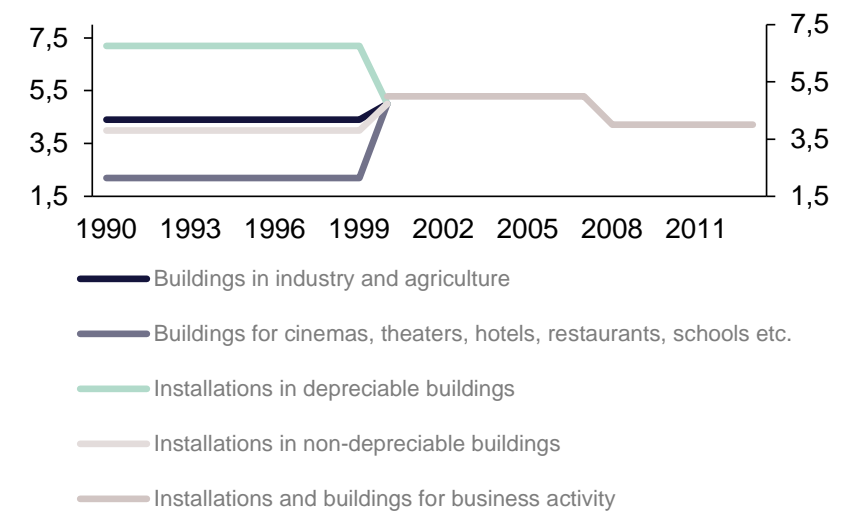

Figure 5. Building and installations

Source: The Danish Ministry of Taxation

$\%$

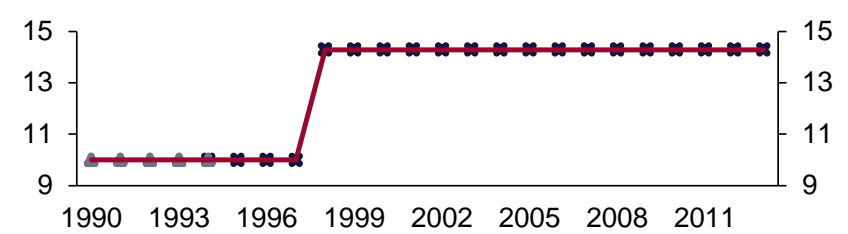

$\longrightarrow$ - Goodwill and some immaterial assets

$\longrightarrow$ Some immateriel assets

Knowhow and patent rights

Figure 6. Intangible assets

Source: The Danish Ministry of Taxation

As for buildings and installations the opposite development has taken place. From various depreciation rates until 2000 the rules were simplified and rates were aligned to just one rate, which was lowered marginally to reach $4 \%$ from 2008 , cf. figure 5 .

In terms of immaterial assets these have been taxed at a uniform rate, but as of 1994 a distinction was made between the rules on depreciation of goodwill, other immaterial assets, and investments in pa- 
tents and knowhow. R\&D-expenses can either be expensed or depreciated over four years.

\section{Investments}

The effect of capital taxation including CIT on the level of investments and thereby the total capital stock is part of the explanation of the development in the CIT base.

Investments have not received particular attention in relation to the tax base, but investments are part of the discussion of what has caused the weak recovery of the Danish economy. Low investment levels have been identified as one of the reasons for a longer period of weak labor productivity growth in Denmark. Investments are relevant for this discussion as the total capital stock affects labor productivity because labor productivity increases with a higher level of production equipment available.

For a small open economy like the Danish the international capital markets is a challenge for the taxation of capital in Denmark. The level of investments is highly sensitive to the taxation of capital as investors compare the after-tax return of investments across borders. Even a minor worsening of the after-tax returns can lead to capital being invested abroad instead of in Demark or profit being shifted to other countries as capital often is a highly mobile tax base and is becoming increasingly more mobile.

\subsection{Overview of Danish capital taxation}

The main capital taxes in Denmark are the corporate income tax, the personal capital income tax, the property value tax, ${ }^{4}$ the share income tax, and the taxation of returns in the pension funds.

\subsection{Corporate taxation}

The statutory CIT rate has been reduced significantly since 1990. However, when a corporation considers whether to undertake an investment the statutory CIT rate is not crucial but rather the effective CIT rate where depreciation rules and other rules concerning the taxable income is taken into account. I.e. if depreciation rates in the tax laws are favorable compared to the true economic depreciation it will reduce the effective cost of investment and thereby reduce the effective taxation of the returns on investments.

Not treated in this paper. 
Marginal investment decisions (e.g. to expand an existing production facility) are decided by the effective marginal tax on corporate income (EMTR) while decisions regarding location of investments (e.g. in which country to locate a new production facility) are primarily decided by the effective average tax on corporate income (EATR).

According to a study carried out for the EU Commission ${ }^{5}$ the gap between the statutory CIT tax rate and the EMTR and the EATR in Denmark has been reduced twice from 1998 to 2011. The first reduction in the gap took place in 2005 and the second in 2008. Both reductions were consequences of CIT reforms where lowering the CIT rate was partly or fully financed by widening the tax base. Despite the widening of the tax base during the reforms the lower CIT rate led to a decrease in the effective CIT rates. In 2012 the gap increased due to the investment window (cf. section on depreciation rates), which caused the effective CIT rate to drop again while the statutory CIT rate remained unchanged.

As depicted in figure 7 and figure 8 decreasing EMTR- and EATR rates indicate, that the incentive for corporations to increase investments or place production in Denmark have increased since 1998 (all else being equal), but the effect on investments will of course also depend on effective tax rates in other countries.

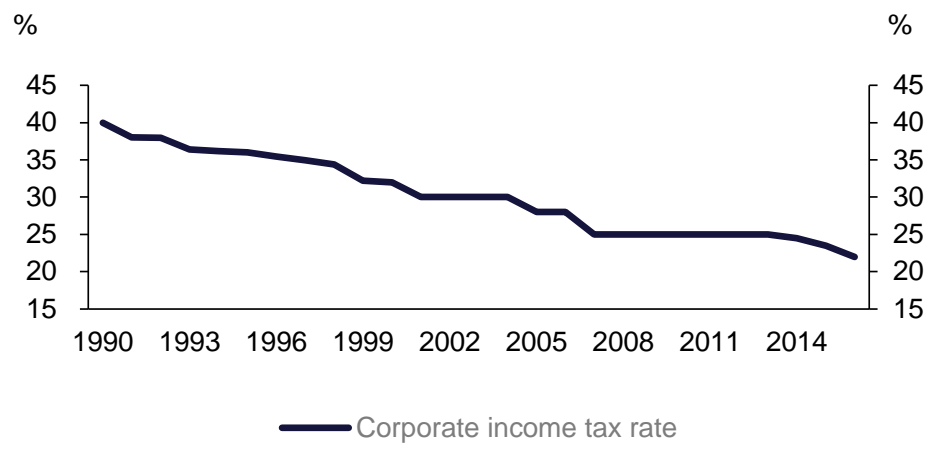

Figure 7. Statutory CIT rate

Source: Formal tax rate: Danish Ministry of Taxation. Effective tax rates: EU commission (study by ZEW), see foot note 6 .

5 Centre for European Economic Research (ZEW) - Project for the EU Commission - Effective tax levels, 2012. It is necessary to make certain reservation when evaluating estimated EMTR and EATR as the methods typically can not capture all effects of the corporate taxation system. I.e. possibilities of tax postponement in the tax rules are typically not included in the calculations. 


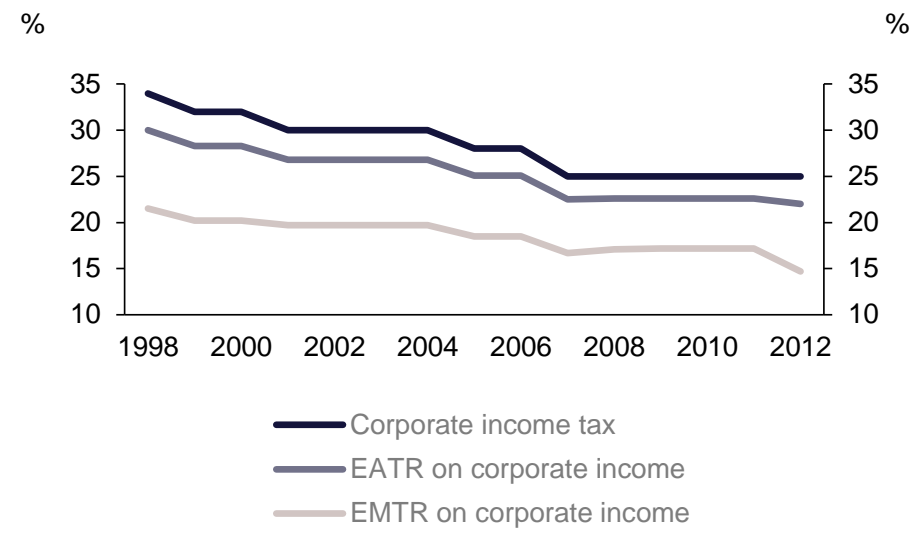

Figure 8. Statutory and effective CIT rates

Source: Formal tax rate: Danish Ministry of Taxation. Effective tax rates: EU commission (study by ZEW), see foot note 6 .

\subsection{Taxation of personal capital income}

The domestic personal capital income taxation affects the level of savings in households and which assets to invest in. Whether taxation of personal capital income affects corporate investments depends on corporations' access to capital.

If capital flows freely across borders domestic taxation of personal capital income does not directly affect the level of real investments made by corporations in Denmark if the marginal investment incentive is determined by e.g. an overseas pension fund, another foreign investor or if domestic investors compare the return on domestic equity to similar foreign assets. In this case, domestic capital income taxation affects the level of household savings but not business investment. A criticism of the personal capital income tax is therefore that it reduces the wealth and thereby the future consumption potential of Danish households.

If on the other hand, a domestic household investor is the relevant supplier of marginal investment capital then domestic business investment will be affected by the combined tax burden at corporate and household level. The condition of free flows of capital across borders is typically not fulfilled for minor corporations as foreign capital providers may be less willing to provide capital to small corporations due to e.g. monitoring considerations. This means that taxation of personal capital income from shares in these corporations will lead to shareholders demanding higher returns on their investments thereby increasing the financing costs of the corporations, which reflects the 
burden of taxes levied at the investor level. This will lead to less corporate investments.

In the following a brief run through of the personal capital income taxation is given.

Share income and other personal capital income

In Denmark share income is taxed progressively. In 2014 the rates are 42 and $27 \%$, respectively, with a threshold of DKK 49.200. Other positive capital income ${ }^{6}$ is included in the tax base for the bottom- and top income tax bracket (and middle income bracket tax until this was abolished in 2009)..$^{7}$ In 2010 a tax ceiling on capital income was introduced, which gradually reduces the highest rate on capital income to $42 \%$ in 2014, cf. figure 10 .

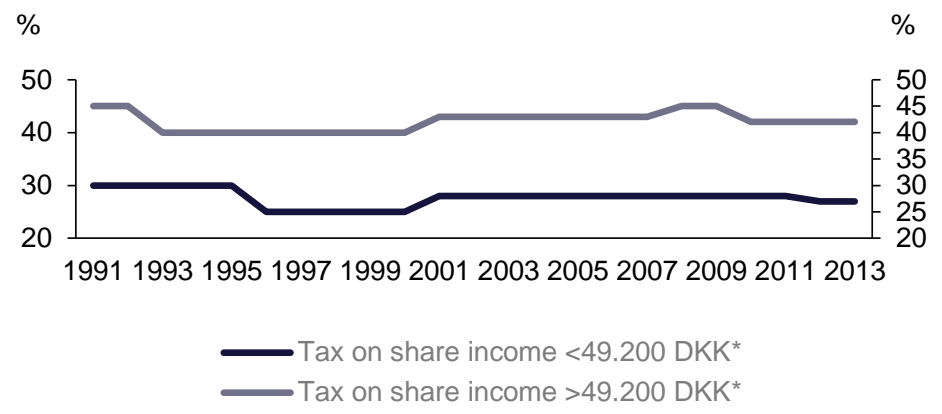

Figure 9. Tax om share income

*2014-level. MTR: Marginal tax rate. source: Danish Ministry of Taxation

6 E.g. gain on bonds, interest etc. Negative capital income below DKK 50.000 has a tax value in 2013 around $33.6 \%$ in an average municipality and 31.6\% above DKK 50.000 .

7 In the 2009 tax reform (Forårspakke 2.0) the middle income bracket tax was abolished and the bottom income bracket tax lowered. 
$\%$

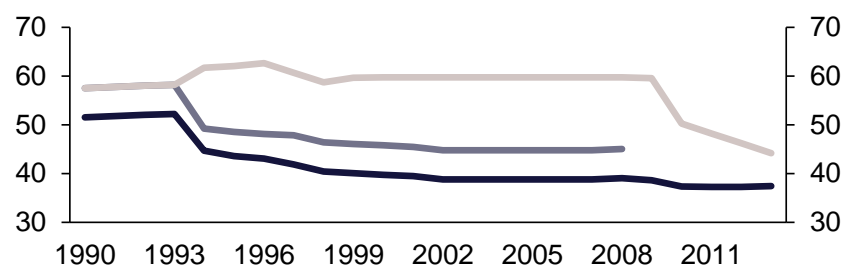

MTR - lowest pos. capital income
MTR - middle pos. capital income
MTR - highest pos. capital income

Figure 10. Tax om other personal capital income

Where other capital income is included in the base for personal taxation, the tax on share income is aligned to the tax rates on labor income. Figure 11 shows how the combined CIT rate and share income tax rate have been adjusted to approximately correspond to the highest marginal tax rate on labor income from 2010. This was done to reduce incentives to transform labor income into lower taxed capital income. ${ }^{8}$ The marginal tax rate on self-employed (on average) is significantly below the marginal tax rate on shareholders, cf. figure 12 . This is a consequence of relatively low earnings among the self-employed in Denmark.

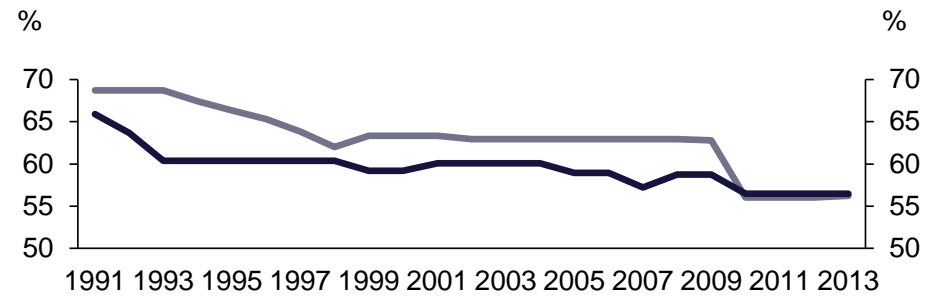

MTR on highest income

$\longrightarrow$ CIT + share income tax

Figure 11. Combined marg. tax on shareholders

8 This problem primarily concerns majority shareholders who can control whether the firm should pay out dividends. 


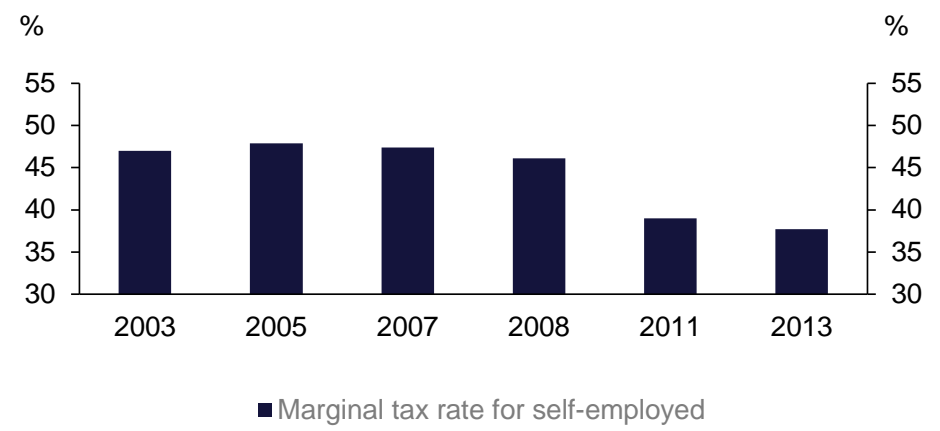

Figure 12. Marginal tax on self-employed

Note: The drop in the marginal tax rate on self-employed from 2008 to 2011 is a consequence of the 2009 tax reform (Forårspakke 2.0) where the middle income bracket tax was abolished, the bottom income bracket tax lowered and the top tax threshold was increased.

Source: Danish Ministry of Taxation

Until year 2000 the base of the tax on return of investments made by pension funds were returns on bonds, mortgage deeds and real estate upon realization. The rate was $44 \%$ in 1990 increasing to $53.5 \%$ in 1994 where after it was lowered to $26 \%$ in 2000 . From 1998 returns on shares were also taxed at a rate of $5 \%$ upon realization.

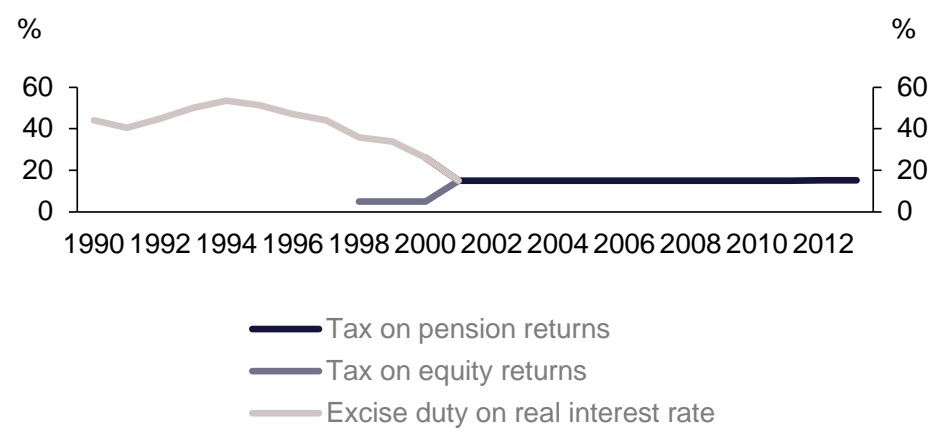

Figur 13. Tax on returns in the pension sector

Note: Until 2001 the tax on returns in the pension sector was only on realized returns whereas from 2001 both realized and unrealized returns are subject to taxation.

Source: Danish Ministry of Taxation

From 2001 all returns (realized as well as unrealized) on investments by pension funds no matter the source was taxed at a relatively low 
level at 15\% and 15.3\% from 2012 and onwards, cf. Figure 13. The low level of taxation of returns on investments by the pension funds has led to a major part of the savings in Denmark being placed in pension savings.

\subsection{Gross investments}

From 1990 until 2008 the Danish level of gross investments in nonfinancial corporations as per cent of GDP has been relatively constant at an average of $12 \%$.

Since 2007 gross investments have dropped around per centage points to app. 10\% of GDP in 2010 from where they appear to have stagnated, cf. figure 13. A lower level of investment will result in a reduction of the (real) capital stock over time. After growing from $150 \%$ of GDP 2006 to $170 \%$ in 2009 the capital stock dropped again in 2010 to $160 \%$ of GDP, cf. figure 15 .

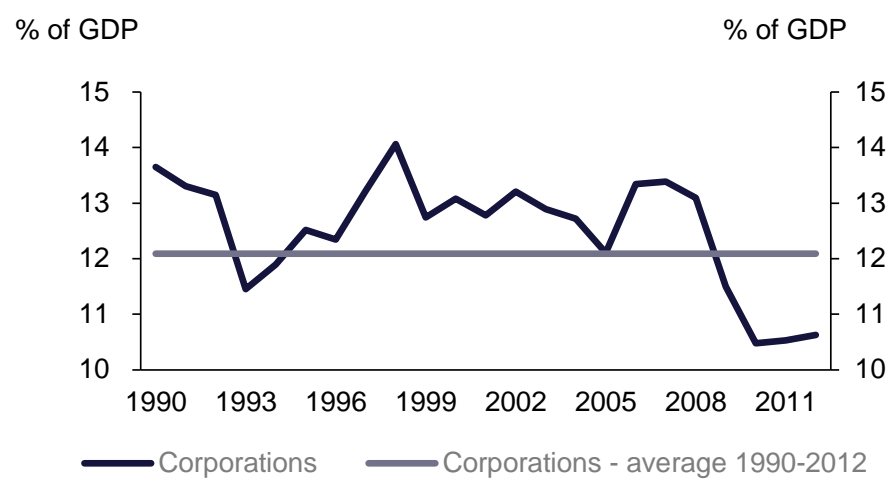

Figure 14. Gross investments

Source: Statistics Denmark 


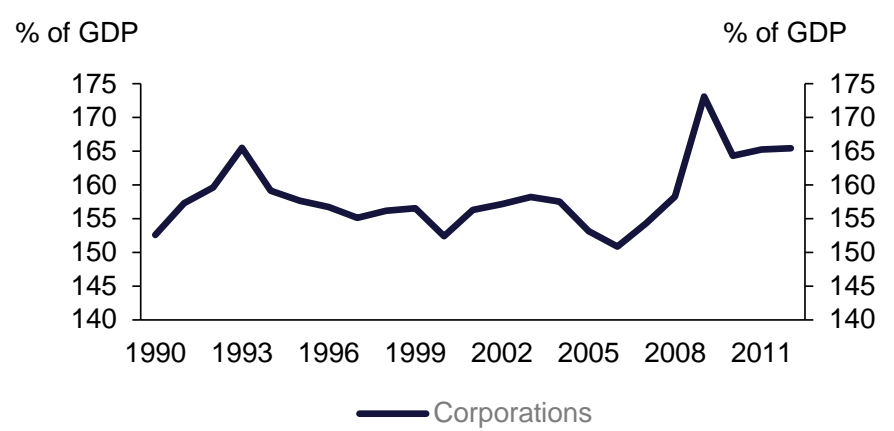

Figure 15. Real capital stock

Source: Statistics Denmark

\subsection{Foreign Direct Investments (FDI)}

Part of the development in gross investments and capital stock and economic growth is related to foreign direct investments. Therefore FDI has received attention in the public debate. ${ }^{9} \mathrm{FDI}$ is pointed out as being especially growth promoting as foreign investors bring along know-how that will lead to a further increase in productivity compared to domestic investments. ${ }^{11}$

However, FDI does not only include real investments, but also changes in market cap for existing companies. The development in FDI does not give insights to the distribution of real investments versus market value fluctuations. Even so, FDI can potentially serve as an indicator of the overall investment level.

Inbound FDI per year has fluctuated between $1-11 \%$ of GDP since 1999, cf. figure 16. There does not seem to be a direct correlation between total investments in (non-financial) corporations and inbound FDI but it appears that inbound FDI has contributed to keep up total investments in 2010-2011.

Since 1999 the stock of Danish outbound FDI has increased from around $25 \%$ to just more than $70 \%$ of GDP and appears to keep growing while the stock of inbound FDI only has risen from $25 \%$ to just below $45 \%$ in 2009 from where it stagnated. 10

9 Increasing FDI does not necessarily contribute to increased economic growth. FDI in form of investments in new firms and capital increases or groupinternal loans that increases the potential for higher investments can contribute to growth while FDI in the form of acquisition of existing firms does not unless the foreign owners introduce know-how etc.

10 The development in Stock FDI also includes increase in value of previous investments and therefore does not only show the development in new investments. 
There are several possible explanations of the development in FDI. The stagnation in inbound FDI could indicate that it has become less attractive to invest in Denmark compared to other countries even though the effective CIT rate has dropped. Another part of the explanation could be that capital is becoming increasingly mobile across borders. Finally, increasing outbound FDI can be a sign of increased use of profit shifting.

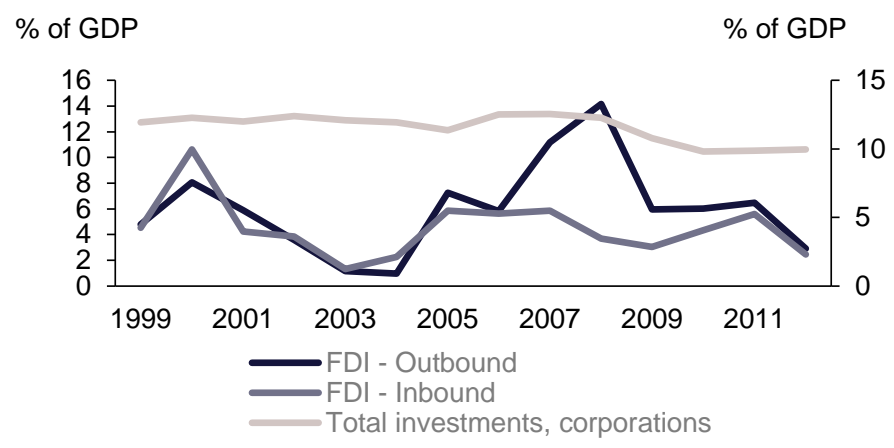

Figure 16. FDI per year

Source: The Danish Central bank

Note: FDI corrected for special purpose entities, SPE and reversed FDI (when FDI is sold).

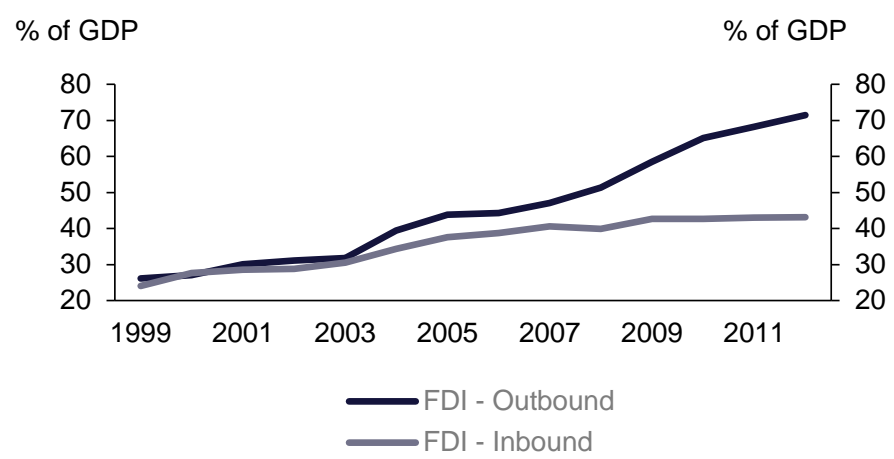

Figure 17. Stock FDI

Source: The Danish Central bank

Note: FDI corrected for special purpose entities, SPE and reversed FDI (when FDI is sold).

To sum up gross investments have declined since 2007 in historical comparison and the growth rate in the stock of FDI seems to have di- 
minished. However, from the stock FDI it cannot be determined whether the divergence in inbound and outbound FDI is caused by international tax competition, profit shifting or other factors.

\subsection{Addressing low investments}

7.6.1. The productivity commission

To investigate the cause of the low productivity growth in Denmark and give advice on how to improve the productivity growth rates the Danish government established the so-called Productivity Commission in March 2012. The Productivity Commission has looked into the development in investments in Denmark.

If there was an underlying problem with the level of investments it may be a sign that the effective CIT is too high compared to international levels. The Productivity Commission found that the drop in investments in 2009-2011 was primarily related to the recession and to a less degree due to underlying problems with investments. ${ }^{11}$

\subsubsection{Growth Plan DK to combat low investment levels}

The low levels of investments in the later years were among the main arguments for lowering the Danish CIT as part of the Growth Plan DK. The main features of the reform are described in box 1 above.

By lowering the CIT rate it becomes more attractive to invest in Denmark. ${ }^{12}$ This argument was followed by a concern about the CIT rate cuts in the countries Denmark usually compares itself to, e.g. Sweden, Norway and Great Britain. Though it was claimed that the government did not want to participate in a race to the bottom it was found necessary to reduce the CIT rate.

To make certain that the three-per centage point CIT rate reduction in the Growth Plan DK would lower the effective CIT rate, this rate cut was neither financed by widening the CIT base nor by raising other taxes but was instead financed by reforms of public transfer systems and lower public spending.

Another argument for the CIT rate cut was the positive effects on the non-neutral tax treatment of returns on equity and debt-financed investments. Financing costs on debt-financed investments (interest) are deductible in the taxable income while financing costs on equityfinanced investments are not. A lower CIT rate reduces the tax value of the interest allowances and thereby makes equity financing relatively more attractive. This may lead to more risky investments with

11 The Danish Productivity Commission: Analyserapport 1: Danmarks produktivitet - hvor er problemerne? April 2013.

12 The government, March 2013: Vækstplan DK - Stærke virksomheder, flere job. 
higher expected returns, which are typically more difficult to finance with debt as creditors are often more risk-averse in comparison to the corporations themselves. As another consequence the more symmetrical treatment of debt and equity would lead to more solid companies if investments to a larger extend are equity financed.

Also, the non-neutral handling of profits and deficits is currently part of the public discussion as the Productivity Commission has suggested removing the limitation on the possibility of carrying forward previous year's deficits in current profits when calculating taxable income. This limitation was imposed as part of the budget for 2012 to reduce corporation's possibilities of using tax planning to avoid paying taxes over a longer period of time. The rule makes it less attractive to undertake investments with high returns and risk as the effective tax rate on these investments increases when deficits cannot fully be deducted.

Finally, an argument for lowering the CIT tax rate was the effects on profit shifting. This is the subjects of the next section.

\subsection{Profit shifting}

Profit shifting can happen through different channels; debt structure, e.g. internal debt shifting and thin capitalization, and via transfer pricing mechanisms. In practice lowering CIT payments can take place when corporations explore the different tax regimes across borders.

\subsubsection{Transfer pricing}

MNEs can to some extend use the prices on intra-group transactions among other prices on royalties when using immaterial rights - to transfer surplus from subsidiaries in high tax countries to subsidiaries in low tax countries. Reducing the CIT rate lowers the "saved tax" from transfer pricing and thus the incentive to make use of transfer pricing, which has a positive effect on the revenue loss from a CIT cut.

\subsubsection{Capital structure}

In the Danish corporate tax system, debt and equity are not treated symmetrically. The bias is towards favouring debt. This is caused by net financing costs (interest rate expenses) being deductible in the taxable income, while the normal return on equity cannot be deducted from the taxable income. However, by transferring equity to low-tax countries and taking up loans in Denmark, corporations are able to lower the tax payments.

Lowering the CIT rate reduces the tax bias towards debt-financed investments. Therefore revenue will to a larger extend be placed in Denmark. 
In Denmark numerous steps have been taken in order to address profit shifting (cf. the section on tax reforms and the legal part of the Danish national report). But even though these legal steps lower profit shifting incentives, they are inferior to addressing profit shifting via initiatives through the CIT rate as profit shifting is primarily dependent on the CIT rate; cf. the estimated effects on the tax base from reduced CIT below.

Lowering the CIT rate in Denmark will in some cases make is less attractive to place revenue abroad and in other cases make it more attractive to place revenue in Denmark. On this basis, lowering the CIT rate will imply a positive behavioural effect. From a purely national view, a CIT rate reduction has positive behavioural effects on companies' incentives to make use of profit shifting. However, from an international standpoint, if these intra-group transactions as a symptom of the base erosion and profit shifting problem is to be properly addressed, there is a need for international cooperation on harmonizing CIT regimes.

\subsubsection{Estimating the effects of a CIT rate cut on profit shifting}

The estimated positive behavioural effect of a CIT rate reduction on lower profit shifting is rather remarkable. When estimating the effect of the three-per centage point decrease of the CIT rate in the Growth Plan DK, it was assumed that profit shifting will happen through the two channels as described above - transfer pricing and capital structure.

Huizinga and Laeven $2007^{13}$ have estimated that the Danish CIT base will increase by $1.37 \%$, when the CIT rate is lowered by one-per centage point. This semi-elasticity has been applied to the Danish Ministry of Taxation's CIT model and forms the basis for estimating the profit shifting effects as part of the behavioural responses to the CIT rate decrease.

When applying their semi-elasticity, profit shifting accounts for the vast majority of positive behavioural effects of the CIT rate cut in the Growth Plan DK.

Even though it is not possible to measure the actual profit shifting, which has taken place over the years, there is little doubt, that the concurrent CIT rate reductions have reduced the incentive to make use of profit shifting and thereby - when seen in isolation - has led to

13 Harry Huizinga and Luc Laeven: International Profit Shifting within Multinationals: A Multi-Country Perspective, IMF and CEPR, 2007. Huizinga and Laeven consider profit shifting arising from international tax differences between affiliates and parent companies as well as from tax differences between affiliates in different host countries. 
an increase in the tax base. As mentioned the development in the Danish CIT base does not indicate increasing problems with profitshifting. It may actually be that the development in the Danish CIT has caused a fiscal externality on other countries that have not reduced their CIT rate by attracting tax base to Denmark from these countries. This may underline the hypothesis that small countries stand to gain the most by tax competition as their tax base is more sensitive (elastic) to the CIT rate.

\section{Development in CIT tax base - Other explanations}

The previous sections showed that the development in the capital taxation including the CIT or the developing in depreciation allowance rules does not explain the non-increasing tax base since 2007 as incentives to invest has increased and depreciation rates are tightened.

It cannot be rejected that part of the explanation of the nonincreasing tax base since 2007 is due to an increase in the use of profit shifting, but the lowering of the CIT and the legal measures addressing profit shifting in the 2007 reform should on the other hand have reduced profit shifting incentives.

As the non-increasing tax base since 2007 coincides with the beginning of the recession the explanation may be found in the development in earnings in different sectors and how these are affected by business cycles as the CIT base is sensitive to business cycles.

The main sources of CIT revenue is trade and transport, industry and construction and the financial sector. From 1996 to 2005 the share of the CIT base from raw material extraction (primarily gas and oil production) has also increased.

The financial sector and trade and transport's share of the tax base increased from the mid-1990's to around 2007 and in the same period contributed significantly to the growth in the tax base (in \% of GDP), cf. figure 18.

After 2007 these sectors contribution to the tax base dropped again while the contribution from other sectors was relatively constant. The growth in the tax base in 2012 can primarily be ascribed to higher earnings in industry, utility companies and construction.

The non-increasing tax base from 2007 until 2012 can thereby to a high degree be isolated to the development in earnings in the financial sector and trade and transport. 


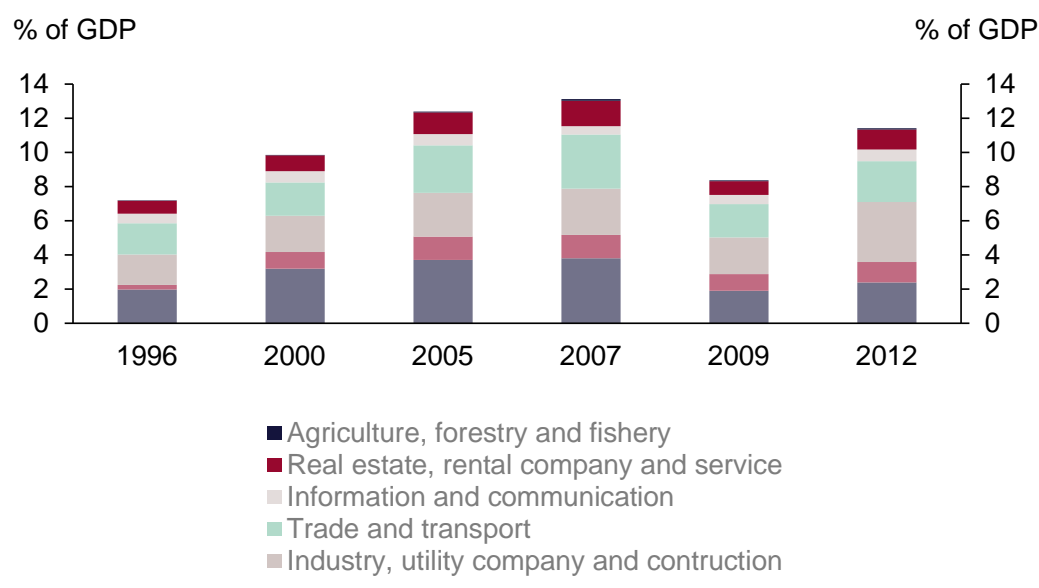

Figure 18. Tax base in $\%$ of GDP - sector allocated

Source: Statistics Denmark

Earnings in the financial sector and in trade and transport are extremely sensitive to business cycles. During years with high growth the financial sector experiences less defaults on loans and higher earnings from share income etc. and vice versa during recession. Earnings in trade and transport are connected to the development in consumption and exports where the growth in both reduced significantly during the recession.

\section{Concluding remarks}

Describing the development in the CIT tax base is a comprehensive and complex task and to pin-point one single cause is not possible. But it is possible to point to realistic explanations on elements, which have contributed to the development.

From the variables considered in this paper, it can not be rejected, that the development in the CIT base has happened through a number of channels. First there is an effect of business cycles in general. There is a causal effect from economic growth to increased activity and investment, which again have a positive effect on economic growth rates and vice versa. Not surprisingly the legal measures such as thin capitalisation rules and tightening of depreciation rates broadens the tax base. Also the reductions of the CIT rate broaden the CIT base through less propensity to profit shift, increased investments and hence larger capital stock and thus increased productivity. Even though it is beyond the scope of this paper to estimate the size of these 
effects, it is however very likely that they have all had an effect on the CIT base.

\section{The challenge ahead for policy makers}

The increased international level of tax competition as well as corporations' abilities to lower their tax payments by making use of the differences in tax regimes across boarders puts a pressure on CIT bases. From an economic point of view corporations can hardly be blamed for acting in a profit maximizing manner.

The task for tax policy makers is to design a tax system, that does not only secure a sufficient level of investments, and thereby also a tax system, that is internationally competitive. Even though lowering the statutory CIT rates has a wide range of positive effects on investments, capital structures, profit shifting etc. CIT revenue is still essential as a financing source in Denmark as in other countries. Therefore there is a boundary to how much CIT rates can be lowered. Even though the Danish CIT rate may be above its optimal level, the issue of perceived fairness - e.g. a publically perceived mismatch between lowering taxes for the corporate sector and keeping personal income taxes high - is still prevalent. This forces tax polity makers to look for alternative financing sources. The alternative financing of the latest tax reform, the Growth Plan DK can be seen as a result of this.

From a purely economic point of view further reductions of the Danish CIT rate would have beneficial effects on the economy through increased investments, higher productivity, increased wage levels etc. However, further CIT cuts may not be that straight forward due to the public debate about fairness.

If base erosion and profit shifting alongside increased international CIT competition post a threat to CIT bases, this is underpinning the importance of designing tax regimes that addresses these. 